\title{
ANALISIS PENYELESAIAN SENGKETA TANAH MELALUI JALUR MEDIASI DI DESA BONTOMANAI KECAMATAN MANNGARABOMBANG KABUPATEN TAKALAR
}

\author{
Land Dispute Settlement Analysis Through Mediation in Bontomanai Village, Manngarabombang \\ District, Takalar Regency
}

\author{
Kurniati $^{1}$, Baso Madiong ${ }^{2}$, Zulkifli Makkawaru ${ }^{2}$ \\ ${ }^{1}$ Pemerintah Desa Bontomanai, Kecematan Mangngarabombang, Kabupaten Takalar \\ ${ }^{2}$ Program Studi Ilmu Hukum, Program Pascasarjana, Universitas Bosowa \\ Email: knia11133@gmail.com \\ Diterima: 10 Januari 2021 \\ Dipublikasikan: 07 Juni 0221
}

\begin{abstract}
ABSTRAK
Sengketa tanah merupakan hal yang sering terjadi dan salah satu perkara yang paling banyak diajukan ke pengadilan. Dalam penelitian ini, peneliti menggunakan metode penelitian hukum empiris. Dikarenakan penelitian ini meneliti orang dalam hubungan hidup di masyarakat maka metode penelitian hukum empiris dapat dikatakan sebagai penelitian hukum sosiologis. Dalam menyelesaikan perkara sengketa dilakukan sebuah mediasi dari kedua belah pihak yang dilakukan seorang camat dan melakukan penandatangan surat perjanjian damai. Camat melaksananakan mediasi atau mendamaikan kedua belah pihak hanya sebatas menengahi permasalahan masyarakatnya agar diselesaikan secara kekeluargaan. Camat sebagai pemerintah setempat sudah seharusnya tidak tinggal diam apabila terjadi kekacauan di dalam masyarakatnya. Hasil mediasi dalam penyelesaian sengketa pertanahan di Kecamatan Manngarabombang, Kabupaten Takalar berhasil mencapai kesepakatan perdamaian antara kedua belah pihak.
\end{abstract}

Kata Kunci: Sengketa Tanah; Mediasi; Camat Mangngarabombang;

\begin{abstract}
Land disputes are a frequent occurrence and one of the most cases brought to court. In this study, researchers used empirical research methods. Because this study examines people in the relationship of life in society, the empirical legal research method can be said as sociological legal research. In resolving the dispute case, a mediation between the two parties is carried out by a district head (Camat) and signing a peace agreement. Camat carries out mediation or reconciles the two parties only to mediate the problems of the community so that they are resolved amicably. Camat as the local goverment should not remain silent when there is chaos in the community. The results of mediation in resolving land disputes in Mangngarabombang district, Takalar Regency succeeded in reaching a peace agreement between the two parties.
\end{abstract}

Keywords: Land Disputes; Mediation, Camat of Mangngarabombang;

\section{PENDAHULUAN}

Hampir di setiap daerah di Indonesia tidak pernah lepas dari sengketa tanah, baik rakyat sesama rakyat, rakyat dengan perusahaan, maupun rakyat dengan pemerintah itu sendiri. Sengketa tanah merupakan salah satu perkara yang paling banyak diajukan ke pengadilan. Masalah tanah yang terjadi di tengah-tengah masyarakat terus mengalami peningkatan dan semakin kompleks, sehingga di pengadilan terjadi ketidak-seimbangan antara masalah yang diajukan dengan proses penyelesaian yang dianggap lambat.

Menurut Mudjiono, ada beberapa faktor yang menyebabkan timbulnya sengketa tanah, yaitu; (1) peraturan yang mengatur soal tanah belum lengkap, (2) ketidaksesuaian peraturan, (3) pejabat pertanahan yang kurang tanggap terhadap kebutuhan tanah dan jumlah tanah yang tersedia, (4) sumber data yang belum akurat dan lengkap, (5) adanya sejumlah data tanah yang keliru, (6) kurangnya sumber daya manusia yang bertugas menyelesaikan sengketa tanah, (7) transaksi tanah yang keliru, (8) adanya penyelesaian oleh instansi lain sehingga timbul tumpang tindih kewenangan.

Sengketa tanah pada hakikatnya memiliki beberapa sifat, diantaranya; pertama, sengketa tanah bersifat administratif, kedua sengketa tanah bersifat perdata, dan ketiga sengketa tanah bersifat pidana. Sengketa tanah yang bersifat perdata merupakan sengketa yang melibatkan individu dengan individu lain dengan karakteristik yang berbeda dengan sengketa perdata pada umumnya. Di mana masing-masing individu saling menuntut hak dan kewajibannya. Dalam hal ini, maka para pihak yang bersengketa tidak lepas dari peran pemerintah (Badan Pertanahan Nasional). Sementara sengketa tanah yang dapat diselesaikan melalui mediasi di luar pengadilan adalah sengketa tanah dalam ruang lingkup perdata yang berada di luar kewenangan kementerian.

Dengan berbagai alternatif penyelesaian sengketa telah dilakukan mulai dari jalur pengadilan (litigasi) maupun jalur mediasi (non-litigasi). Sebenarnya, penyelesaian sengketa di luar pengadilan (non-litigasi) 
terdapat beberapa jenis, seperti negosiasi, mediasi, dan arbitrase. Setiap sengketa tanah memerlukan penyelesaian, baik dengan cara litigasi maupun nonlitigasi. Penyelesaian sengketa non litigasi disebut juga dengan alternatif yang dilakukan di luar pengadilan untuk memperoleh kepastian hukum dengan cara yang lebih murah, lebih efisien, lebih cepat dan menguntungkan kedua belah pihak. Dalam ketentuan Pasal 1 angka 10 Undang-Undang Nomor 30 Tahun 1999 tentang Arbitrase dan Alternatif Penyelesaian Sengketa, alternatif penyelesaian sengketa adalah lembaga penyelesaian di luar pengadilan dengan cara konsultasi, negosiasi, mediasi, konsiliasi atau penilaian ahli.

Mediasi merupakan cara penyelesaian sengketa secara damai yang tepat, efektif, dan dapat membuka akses yang lebih luas kepada para pihak untuk memperoleh penyelesaian yang memuaskan serta berkeadilan. Bahkan di pengadilan sendiri, khusus mengenai perkara perdata diharuskan terlebih dahulu melakukan mediasi sebelum diperiksa perkaranya oleh hakim. Sebagaimana ketentuan hukum acara perdata Pasal 154 Reglemen Hukum Acara untuk daerah luar Jawa dan Madura (Reglement Tot Regeling Van Het Rechtswezen In De Gewesten Buiten Java En Madura, Staatsblad, 1927) dan Pasal 130 Reglement Indonesia yang diperbaharui (Het Herziene Inlandsch Reglement, Staatsblad, 1941) mendorong para pihak menempuh proses perdamaian yang dapat didayagunakan melalui mediasi dengan mengikutsertakannya ke dalam prosedur perkara di pengadilan. Di sisi lain, proses litigasi menghasilkan kesepakatan yang bersifat adversial yang belum mampu merangkul kepentingan bersama, cenderung menimbulkan masalah baru, serta lambat dalam penyelesaiannya. Sebaliknya melalui proses mediasi dapat menghasilkan kesepakatan yang bersifat "win-win solution".

Berbeda dengan mediasi yang dilakukan atas perkara sengketa tanah di Desa Bontomanai Kecamatan Manngarabombang Kabupaten Takalar di mana merupakan mediasi yang dilakukan secara sukarela oleh para pihak dengan pemerintah setempat sebagai mediatornya. Mediator pada perkara tersebut adalah Camat Kecamatan Manngarabombang. Sengketa tanah tersebut merupakan sengketa perbatasan yang telah diperselisihkan selama bertahun-tahun hingga akhirnya tercapai kesepakatan diantara para pihak.,Akan tetapi, yang menjadi persoalan adalah proses mediasi yang dilakukan apakah sudah sesuai dengan ketentuan peraturan perundang-undangan, khususnya PERMA No.1 Tahun 2016 dan Peraturan Menteri Agraria dan Tata Ruang/Kepala Badan Pertanahan Nasional Nomor 11 Tahun 2016 tentang Penyelesaian Kasus Pertanahan serta bagaimanakah kekuatan hukum hasil mediasi tersebut yang hanya dituangkan dalam surat pernyataan kedua belah pihak bahwa telah tercapai kesepakatan, apabila diperhadapkan dengan persoalan hukum kemudian. Serta apakah mediasi yang dilakukan oleh camat termasuk dalam mediasi sukarela dan apakah camat memenuhi persyaratah hukum untuk menjadi mediator dalam penyelesaian sengketa pertanahan.

\section{METODE}

\section{Jenis Penelitian}

metode penelitian yang digunakan adalah penelitian hukum empiris. Dapat dikatakan sebagai penelitian hukum sosiologis yang diambil dari fakta-fakta yang ada di dalam suatu masyarakat, badan hukum atau badan pemerintah.

\section{Pendekatan Masalah}

Dalam penelitian ini, ada dua metode pendekatan masalah yang digunakan, yaitu; pertama, pendekatan dan Kedua,Pendekatan empiris

\section{Lokasi Penelitian}

Lokasi penelitian pada penelitian ini dilakukan di Kantor Kecamatan Manngarabombang Kabupaten Takalar dan Kediaman Para Pihak yang bersengketa Jenis dan Sumber Data

1. Data Primer merupakan data yang diperoleh secara langsung dari lapangan berdasarkan dari wawancara dengan responden dan narasumber yang tepat.

2. Data Sekunder merupakan data dari studi pustaka yang ditelaah secara seksama dan kemudian dihubungkan dengan objek penelitian.

Teknik Pengumpulan Data

1. Penelitian Lapangan (Field Research), Dalam melakukan penelitian lapangan, penulis menggunakan teknik wawancara.

\section{Penelitian Pustaka (Library Research)}

Analisis Data

Analisis data dilakukan untuk mengolah data primer dan data sekunder sebagaimana yang tersebut di atas dengan menggunakan analisis yuridis deskriptif, hasil wawancara, dan studi kepustakaan

\section{HASIL DAN PEMBAHASAN}

Proses Pelaksanaan Mediasi Penyelesaian Sengketa Pertanahan di Kecamatan Manngarabombang Kabupaten Takalar

1. Gambaran Umum Perkara

Sengketa pertanahan bermula diantara dua orang bersaudara yaitu, Baso dan Hasanyang saling mengklaim satu petak sawah seluas $264 \mathrm{~m} 2$ yang merupakan milik orang tuanya (Baso dan Hasan). Menurut keterangan Muhammad Aris selaku Kepala Desa Bontomanai, dari keterangan yang disampaikan oleh kedua belah pihak dan para saksi, sengketa bermula saat awal memasuki musim hujan, di mana Baso menggarap sawah tersebut dan menabur benih padi, sebagaimana kebiasaan orang di Kabupaten Takalar memulai menanam padi jika telah memasuki awal musim hujan.

Hasan yang merupakan kakak kandung (saudara) Baso datang dan mengklaim sawah tersebut bahwa seperduanya adalah miliknya dengan alasan bahwa dia (hasan) juga berhak atas sawah tersebut karena saudara lebih tua 
dengan Baso. Menurut Hasan, sawah tersebut harus dibagi dua karena dianggap sebagai warisan peninggalan orang taunya. Padahal, menurut Baso, sawah tersebut sepenuhnya menjadi miliknya dengan alasan bahwa Baso telah memberikan sejumlah uang dan seekor kerbau besar kepada Hasan sebagai ganti dari sawah tersebut. Anggapan BasobahwaHasan telah menjual seperdua bagian sawah tersebut kepada Basoyang merupakan bagian Hasan dan sawah tersebut menjadi milik Baso sepenuhnya. Kurang lebih delapan belas tahun yang lalu, Hasan meminjam uang kepada Baso sebesar Rp. 5.000.000 (lima juta rupiah) dan satu ekor kerbau besar yang kira-kira jika diaungkan saat ini harganya sekitar Rp. 20.000.000 (dua puluh juta) an lebih. Lebih lanjut Kepala Desa Bontomanai bahwa setelah terjadi bentrokan pertengkaran di lokasi sawah yang di garap, salah satu pihak keluarganya datang melapor ke kantor desa, menyampaikan hal tersebut.Akhirnya Kepala Desa Bontomanai menindak lanjuti permasalahan tersebut dan menyampaikan kepada Kepala Dusun untuk mencari informasi lebih jauh tentang masalah tersebut.

Berdasarkan informasi yang diperoleh dari Pasang Mabe selaku Kepala Dusun Bontopa ja Desa Bontomanai Kecamatan Manngarabombang Kabupaten Takalar, bahwa sawah tersebut merupakan harta peninggalan ayah Hasan dan Baso, artinya sawah tersebut adalah harta warisan. Sementara, menurut penjelasan Kepala Dusun bahwa berdasarkan informasi yang diperoleh dari keluarga dekat Hasan dan Baso bahwa sebenarnya sawah itu telah dibagi dua antara Hasan dan Baso, tetapi Hasan telah meminta sejumlah uang dan seekor kerbau kepada Baso dengan jaminan bagian sawahnya dan apabila uang itu belum dikembalikan maka bagian sawahnya menjadi milik Baso.

Setelah kurang lebih delapan belas tahun berlalu, Hasan mendatangi Baso dan mengklain seperdua sawah itu sebagai miliknya. Hasan juga membawa sejumlah surat-surat kepemilikan sawah tersebut beserta bukti pembayaran pajaknya. Menurut Pasang Mabe selaku Kepala Dusun Bontopa ja Desa Bontomanai bahwa dalam kurung waktu delpan belas tahun itu memang Baso tidak pernah melakukan perubahan kepemilikan sawah, bahkan Baso sama sekali tidak memiliki dokumen atau surat-surat atas sawah tersebut, semuanya ada di tangan Hasan. Juga disertai pergantian Kepala Desan dan Kepala Dusun yang sudah berkali-kali.

Setelah informasi yang dikumpulkan oleh Pasang Mabe selaku Kepala Dusun telah dianggap cukup, maka proses selanjutnya dialihkan kepada Kepala Desa Bontomanai. Kepala Desa segera mengambil tindakan untuk menengahi perkara tersebu. Baso sebagai Pihak Pertama dan Hasan sebagai Pihak Kedua dipanggil ke Kantor Desa Bontomanai untuk diuapayakan perdamaian secara kekeluargaan.

\section{Proses Pelaksanaan Mediasi}

Sebelum mediasi dilakukan, terlebih dahulu camat harus mengetahui jenis sengketanya apakah termasuk kewenangan kementerian atau bukan. Sebagaimana telah dijelaskan sebelumnya bahwa apabila termasuk ke dalam kewenangan kementerian sesuai Pasal 11 ayat (3) Permen ATR/KBPN RI No. 11 Tahun 2016, maka camat tidak memiliki kewenangan untuk menyelesaikan sengketa tersebut. Akan tetapi setelah dilakukan analisis perkara, maka dapat dipastikan bahwa Sengketa Pertanahan di Desa Bontomanai, Kecamatan Manngarabombang, Kabupaten Takalar adalah termasuk sengketa di luar kementerian dan dapat dilakukan mediasi sukarela oleh kedua belah pihak dan camat.

Sesuai ketentuan Pasal 12 Permen ATR/KBPN RI No. 11 Tahun 2016 bahwa;

a. (1). Dalam hal sengketa dan konflik merupakan kewenangan kementerian sebagaimana dimaksud dalam Pasal 11 ayat (3), pejabat yang bertanggung jawab dalam menangani sengketa, konflik dan perkara melaporkan hasil pengumpulan data dalam Pasal 10 dan Pasal 11 kepada Kepala Kantor Pertanahan.

b. (2). Dalam hal sengketa atau konflik bukan merupakan kewenangan kementerian sebagaimana dimaksud dalam Pasal 11 ayat (4), maka pejabat yang bertanggung jawab dalam menangani sengketa, konflik dan perkara menyampaikan penjelasan secara tertulis kepada pihak pengadu.

c. (3). Penjelasan sebagaimana dimaksud pada ayat (2) juga memuat pernyataan bahwa penyelesaian sengketa dan konflik diserahkan kepada pihak pengadu.

d. (4). Penjelasan sebagaimana dimaksud pada ayat (2) dan ayat (3) dibuat sesuai dengan format sebagaimana tercantum dalam lampiran VI yang merupakan bagian yang tidak terpisahkan dari peraturan menteri ini.

e. (5). Dalam hal sengketa atau konflik sebagaimana dimaksud pada ayat (2), kementerian dapat mengambil inisiatif untuk memfasilitasi penyelesaian sengketa atau konflik melalui mediasi.

Karena Sengketa Pertanahan di Desa Bontomanai, Kecamatan Manngarabombang, Kabupaten Takalar merupakan sengketa di luar kewenangan kementerian, maka camat dengan inisiatif sebagai pemerintah setempat dapat melakukan mediasi secara sukarela dengan para pihak. Akan tetapi camat tidak dapat memaksakan kehendaknya untuk memutus perkara tersebut dan juga hasil mediasinya tidak memiliki kekuatan hukum.

Proses mediasi dilakukan dalam jangka waktu yang cukup panjang, yaitu kurang lebih satu tahun lamanya hingga proses mediasi di tingkat kecamatan. Padahal mediasi seharusnya membutuhkan waktu yang singkat, sederhana, dan biaya ringan, serta efisian dan bersifat rahasia. Hal itu dikarenakan pencarian titik temu para pihak yang sangat sulit, para pihak lebih mendahulukan egoismenya masing-masing. Begitu pula dengan Kepala Desa Bontomanai telah berupaya semaksimal mungkin untuk mendamaikan kedua belah pihak tetapi para pihak tidak mendapatkan titik temunya hingga Kepala Desa memberikan arahan kepada kedua belah pihak untuk meneruskan perkaranya ke tingkat kecamatan.

Menurut Muhammad Arif selaku Sekretaris Kecamatan Manngara-bombang Kabupaten Takalar; pada 
tingkat kecamatan, proses mediasi dilakukan dengan melibatkan Kedua belahPihak, Camat sebagai Mediator dan Kepala Dusun, Kepala Desa, Bimmas, Babinsa sebagai saksinya.

Sementara proses pelaksanaan mediasi dilakukan dengan beberapa tahap, yaitu;

a. Pengumpulan Data dan Analisis Permasalahan yaitu camat mempelajari lebih awal sengketa tersebut untuk memperoleh pengetahuan awal.

b. Pemanggilan Kedua Belah Pihak dan Saksi, pada tahap ini camat mendengarkan keterangan dari kedua belah pihak dan beberapa informasi dari para saksi.

c. Penandatangan Kesepakatan, setelah memperoleh titik temu kedua belah pihak, dibuatlah kesepakatan yang dituangkan dalam Berita Acara Mediasi (BAM) ditanda tangani oleh Kedua bela pihak Pihak, Camat sebagai Mediator dan Kepala Dusun, Kepala Desa, Bimmas, Babinsa masing-masing sebagaisebagai saksi dalam Berita Acara kesepakatan tersebut.

Hasil Mediasi oleh Camat dalam Penyelesaian Sengketa Pertanahan di Kecamatan Manngarabombang Kabupaten Takalar

1. Kewenangan Camat Sebagai Mediator dalam Sengketa Tanah

Camat merupakan kepala pemerintahan di tingkat kecamatan yang keududkannya diatur dalam ketentuan Pasal 221 ayat (1) Undang-Undang Nomor 23 Tahun 2014 tentang Pemerintahan Daerah bahwa Daerah kabupaten/kota membentuk kecamatan dalam rangka meningkatkan koordinasi penyelenggaraan pemerintahan, pelayanan publik, dan pemberdayaan masyarakat desa/kelurahan.

Kemudian lebih lanjut diatur dalam ketentuan Pasal 224 UU Nomor 23 Tahun 2014 bahwa;

a. Kecamatan dipimpin oleh seorang kepala kecamatan yang sebut camat yang berada di bawah dan bertanggung jawab kepada bupati/walikota melalui sekretaris daerah.

b. Bupati/walikota wajib mengangkat camat dari pegawai negeri sipil yang menguasai pengetahuan teknis pemerintahan dan memenuhi persyaratan kepegawaian sesuai dengan ketentuan peraturan perundang-undangan.

c. Pengangkatan camat yang tidak sesuai dengan ketentuan sebagaimana dimaksud pada ayat (2) dibatalkan keputusan pengangkatannya oleh gubernur sebagai wakil pemerintah pusat.

Jadi dapat dikatakan bahwa kecamatan dibentuk untuk memudahkan melakukan koordinasi penyelenggaraan pemerintahan di tingkat kecamatan ke bawah. Sehingga camat sebagai kepala pemerintahan kecamatan memiliki tugas dan kewenangan koordinasi. Adapun kewenangan camat diatur dalam ketentuan Pasal 225 UU No. 23 Tahun 2014, yaitu;

a. Camat sebagaimana dimaksud dalam Pasal 224 ayat

(1) mempunyai tugas;
1) Menyelenggarakan urusan pemerintahan umum sebagaimana dimaksud dalam Pasal 25 ayat (6);

2) Mengoordinasikan kegiatan pemberdayaan masyarakat;

3) Mengoordinasikan upaya penyelenggaraan ketenteraman dan ketertiban umum;

4) Mengoordinasi penerapan dan penegakan perda dan perkada;

5) Mengoordinasikan pemeliharaan prasarana dan sarana pelayanan umum;

6) Mengoordinasikan penyelenggaraan kegiatan pemerintahan yang dilakukan oleh perangkat daerah di kecamatan;

7) Membina dan mengawasi penyelenggaraan kegiatan desa dan/atau kelurahan;

8) Melaksanakan urusan pemerintahan yang menjadi kewenangan daerah kabupaten/kota yang tidak dilaksanakan oleh unit kerja perangkat daerah kabupaten/kota yang ada di kecamatan; dan

9) Melaksanakan tugas lain sesuai dengan ketentuan peraturan perundang-undangan.

b. Pendanaan penyelenggaraan urusan pemerintahan umum sebagaimana dimaksud pada ayat (1) huruf a dibebankan pada APBN dan pelaksanaan tugas lain sebagaimana dimaksud pada ayat (1) huruf I dibebankan kepada yang menugasi.

c. Camat dalam melaksanakan tugasnya sebagaimana dimaksud pada ayat (1) dibantu oleh kecamatan.

Selain tugas tersebut di atas, camat juga mendapat pelimpahan wewenang, hal ini diatur dalam Pasal $226 \mathrm{UU}$ No. 23 Tahun 2014 sebagai berikut;

a. (1). Selain melaksanakan tugas sebagaimana dimaksud dalam Pasal 225 ayat (1), camat mendapatkan pelimpahan sebagai kewenangan bupati/walikota untuk melaksanakan sebagian urusan pemerintahan yang menjadi kewenangan daerah kabupaten/kota.

b. (2). Pelimpahan kewenangan bupati/walikota sebagaimana dimaksud pada ayat (1) dilakukan berdasarkan pemetaan pelayanan publik yang sesuai dengan karakteristik kecamatan dan/atau kebutuhan masyarakat pada kecamatan yang bersangkutan.

c. (3). Pelimpahan kewenangan bupati/walikota sebagaimana dimaksud pada ayat (2) ditetapkan dengan keputusan bupati/walikota berpedoman pada peraturan pemerintah.

Dan kewenangan lain oleh camat diatur Peraturan Pemerintah Nomor 17 Tahun 2018 tentang Kecamatan.

Kewenangan camat merupakan suatu kekuasaan secara hukum dalam mengambil tindakan hukum atau keputusan hukum. Kewenangan itu sah apabila memiliki dasar hukum yang memerintahkan untuk mengambil tindakan atau keputusan hukum. Apabila dasar hukumnya tidak ada, maka segala tindakan atau keputusan yang diambil oleh camat tidak dapat mengikat atau tidak memiliki kekuatan hukum. Untuk itu, perlu mengetahui bagaimana kewenangan seorang camat dalam mengambil tindakan atau keputusan, maka harus dilihat tugas dan 
kewenangannya yang diberikan oleh peraturanperundang-undangan.

Terkait dengan tugas dan tanggung jawabnya diatur dalam ketentuan Pasal 10, Pasal 11, dan Pasal 12 Peraturan Pemerintah Nomor 17 Tahun 2018 tentang Kecamatan telah dijelaskan tugas dan kewenangan yang ada pada camat sebagaimana telah dijelaskan pada bab sebelumnya. Di sini penulis sengaja mencantumkan tugas dan kewenangan camat untuk menjadi batu uji apakah camat memiliki tugas dan kewenangan dalam hal penyelesaian sengketa pertanahan apalagi menjadi mediator di dalamnya.

Sementara itu, dari proses pelaksanaan mediasi tersebut, diketahui penulis bahwa proses pelaksanaan mediasi penyelesaian sengketa pertanahan sama sekali tidak melibatkan pihak dari Badan Pertanahan Nasional (BPN). Hal itu disampaikan juga oleh Muhammad Arif selaku Sekretaris Kecamatan Manngarabombang Kabupaten Takalar bahwa selama proses pelaksanaan mediasi tidak pernah dilibatkan BPN karena dianggap tidak perlu.

Berdasarkan ketentuan Pasal 11 ayat (3) Permen ATR/KBPN RI No. 11 Tahun 2016 tentang Penyelesaian Kasus Pertanahan telah menetukan bahwa "sengketa atau konflik yang menjadi kewenangan kementerian sebagaimana dimaksud pada ayat (1) meliputi: kesalahan prosedur dalam proses pengukuran, pemetaan, dan/atau perhitungan luas,kesalahan prosedur dalam proses pendaftaran penegasan dan/atau pengakuan hak atas tanah bekas milik adat, kesalahan prosedur dalam proses penetapan dan/atau pendaftaran hak tanah, kesalahan prosedur dalam proses penetapan tanah terlantar; tumpan tindih hak atau sertifikat hak atas tanah yang salah satu alas haknya jelas terdapat kesalahan, kesalahan prosedur dalam pemeliharaan data pendaftaran tanah, kesalahan prosedur dalam proses penerbitan sertifikat pengganti, kesalahan dalam memberikan informasi data pertanahan, kesalahan prosedur dalam proses pemberian izin, penyalahgunaan pemanfaatan ruang, atau kesalahan lain dalam penerapan peraturan perundang-undangan.

Menurut penulis, mediasi seperti ini merupakan mediasi sukarela yang bisa saja dilakukan oleh pemerintah setempat. Camat meskipun dalam PP Kecamatan tidak diatur kewenangan sebagai mediator, tetapi karena jabatannya bisa saja menjadi mediator sengketa pertanahan. Camat sebagai pemerintah di tingkat kecamatan bisa saja menjadi mediator sengketa pertanahan apabila sengketa itu bukan menjadi kewenangan kementerian sebagaimana dimaksud pada Pasal 11 ayat (1) dan ayat (3) Permen ATR/KBPN RI No. 11 Tahun 2016 tentang Penyelesaian Kasus Pertanahan.

2. Hasil Kesepakatan Para Pihak dan Kekuatan Hukum

Hasil Mediasi

Dalam suatu kesepakatan atau perjanjian damai dari hasil mediasi mestinya memiliki kekuatan hukum karena isinya memuat terjadinya peristiwa hukum diantara para pihak yang membuatnya. Apabila dikemudian hari ada pihak yang tidak beritikad baik dalam melaksanakan prestasi seperti apa yang telah mereka sepakati.

Sementara itu, dalam rumusan Pasal 130 HIR/154 $\mathrm{RBg}$ ayat (2) dan ayat (3) menentukan bahwa;

a. Jika perdamaian yang demikian itu terjadi, maka tentang hal itu pada waktu bersidang diperbuat sebuah akta, dengan mana kedua belah pihak diwajibkan untuk mencukupi perjanjian yang dibuat itu, maka surat (akta) itu akan berkekuatan dan akan dilakukan sebagai putusan hakim yang biasa.

b. Tentang keputusan yang demikian tidak dapat dimintakan banding.

Hal serupa juga dijelaskan oleh Direktur Eksekutif Pusat Mediasi Nasional (PMN), A. Fahmi Shahab tegas mengatakan bahwa hasil kesepakatan pasca mediasi mengikat para pihak. soalnya, kesepakatan tersebut menjadi semacam perjanjian bagi kedua belah pihak yang sudah pasti mengikat karena telah disepakati sebelumnya. Apalagi, hal itu semakin punya kekuatan mengikat tatkala kedua pihak merasa bahwa kesepakatan itu bersifat final.Hasilnya mengikat, karena itu kontrak bagi para pihak. Itu final kalau para pihak menganggap itu final.

Jika demikian, hasil kesepakatan mediasi memiliki kekuatan hukum dan eksekusi serta kekuatan pembuktian yang sempurna. Akan tetapi bagaimana dengan hasil mediasi yang dilakukan oleh camat Manngarabombang Kabupaten Takalar terkait sengketa tanah tersebut. Berikut akan dijelaskan lebih lanjut.

\section{Hasil mediasi sengketa tanah Desa Bontomanai Kecamatan Mannga-rabombang, Kabupaten Takalar}

Penandatanganan kesepakatan tercapai setelah camat berupaya mendamaikan kedua belah pihak. Hasil kesepakatan kemudian dituangkan dalam berita acara perdamaian yang ditandatangani kedua belah pihak dan camat sebagai mediatornya serta para saksi dari kepala desa dan saksi masing-masing kedua belah pihak.

Hasil kesepakatan tersebut diatuangkan dalam Berita Acara Mediasi (BAM) Sebagaimana di Jelaskan oleh Sekretraris Kecamatan Manngarabombang bahwa hasil kesepakatan para pihak dibuat dalam berita acara perdamaian yang ditandatangani oleh para pihak, camat, dan saksi-saksi yang ada. Lebih lanjut Muhammad Arif selaku Sekretaris Kecamatan Manngarabombang menjelaskan "akan tetapi, BAM tersebut tidak ditindaklanjuti dengan akte perdamaian atau sampai di daftarkan ke pengadilan bahkan menurutnya, selama menjadi Sekcam, belum pernah ada perkara yang dimediasi oleh camat yang dibuatkan akta dan disahkan di pengadilan, hanya sebatas kesepakatan yang dituangkan dalam berita acara dan dianggap perkaranya selesai."

Adapun hasil kesepakatannya yaitu sawah yang selama ini penguasaannya oleh Baso diberikan sepenuhnya diberikan kepada Baso dengan pertimbangan bahwa Hasan telah mengambil sejumlah uang dan satu ekor kerbau dari Baso sejak kurang lebih delapan belas tahun yang lalu dan belum dikembalikan ditambah lagi Baso telah memberikan lagi sejumlah uang kepada Hasan 
agar tercapai kesepakatan dan tanah sengketa tersebut menjadi milik Baso seluruhnya.

Dari hasil analisis telah dilakukan, maka menurut penulis bahwa hasil kesepakatan pada sengketa pertanahan di Kecamatan Manngarabombang Kabupaten Takalar sama sekali tidak memiliki kekuatan eksekusi apabila dikemudian hari ternyata salah satu pihak tidak mengikuti isi kesepakatan tersebut. Hal itu dikarenakan hasil kesepakatan tersebut hanya tertuang dalam berita acara yang tidak dibuat dalam akte perdamaian dan di daftarkan di pengadilan negeri. Akan tetapi hasil kesepakatan tersebut hanya dapat digunakan sebagai bukti surat di pengadilan bahwa sebelumnya ternyata sudah ada hasil kesepakatan kedua belah pihak yang bersengketa tetapi tidak dapat di eksekusi. Akta perdamaian yang dapat dieksekusi hanya yang dibuat oleh BPN atau atas perintah pengadilan untuk menunjuk mediator dalam perkara pertanahan yang kemudian di daftarkan di pengadilan negeri.

Faktor Penghambat dalam Pelaksanaan Mediasi Penyelesaian Sengketa Pertanahan di Kecamatan Manngarabombang Kabupaten Takalar

\section{Faktor Pemahaman Hukum}

Salah satu faktor yang menghambat dalam proses penyelesaian sengketa pertanahan adalah faktor hukum. Di mana pemahaman masyarakat akan hukum pertanahan masih sangat minim sehingga apabila telah ada secarik berkas kwitansi masyarakat sudah beranggapan hal itu cukup sebagai bukti kepemilikan tanah. Apalagi jika mereka memiliki bukti SPPT maka seolah-olah tanah itu sudah menjadi miliknya secara hukum. Hal itulah yang terjadi dalam sengketa pertanahan di Kecamatan Manngarabombang Kabupaten Takalar antara Baso dan Hasan. Dengan bukti SPPT yang dimilikinya, mereka beranggapan bahwa tidak perlu lagi mengurus surat beralih kepemilikan.

Sementara itu, salah satu faktor hukum yang menghambat dalam pelaksanaan mediasi penyelesaian kasus sengketa pertanahan di Kecamatan Manngarabombang Kabupaten Takalar adalah pemahaman hukum kedua belah pihak yang minim, tidak mengerti apa itu mediasi, serta di mana harus diselesaikan jika terjadi sengketa pertanahan. Kedua belah pihak juga beranggapan bahwa keputusan camat terhadap suatu sengketa adalah keputusan yang sudah kuat dan tidak perlu lagi diganggu gugat. Hal itu terbukti saat dilakukan Wawancara dengan kedua belah pihak di Dusun Bontopa ja Desa Bontomanai Kecamatan Manngarabombang Kabupaten Takalar bahwa mereka paham dan menyetujui hasil mediasi yang dilakukan oleh camat atas perkaranya dan tidak ditindaklanjuti lagi Berita Acara tersebut karena sudah selesai, untuk apalagi ditindak lanjuti hanya untuk menghabiskan uang.

\section{Faktor Campur Tangan Orang Lain}

Campur tangan pihak luar sangat mempengaruhi jalannya proses mediasi. Pihak luar selalu mencoba mempengaruhi kedua belah pihak untuk saling bertahan pada pendiriannya masing-masing. Hal itu diungkapkan Kepala Desa Bontomanai bahwa keterlibatan pihak luar sangat mengganggu proses mediasi, sangat susah mencapai titik temu kesepakatan karena pihak luar selalu membujuk kedua belah pihak.

Dalam pelaksanaan mediasi, ketidaktahuan para pihak tentang hukum menjadi faktor utama. Para pihak mempertahankan egoismenya masing-masing dengan hanya berpegang pada beberapa dokumen yang tidak terlalu kuat untuk pembuktian dan ditambah lagi surat Surat Pemberitahuan Pajak Terutang (SPPT) yang sudah lama.

Hal itu diungkapkan oleh Sekretaris Kecamatan Manngarabombang, bahwa saat proses mediasi terkadang kedua belah pihak saling bersitegang mempertahankan argumentasinya masing-masing. Hal itu juga diakui oleh Muhammad Aris selaku Kepala Desa Bontomanai saat melakukan upaya mediasi di tingkat desa, dimana kedua belah pihak saling bersitegang hingga akhirnya Kepala Desa memberikan arahan untuk ke tingkat kecamatan

3. Faktor Kurangnya Sumber Daya

Salah satu faktor penghambat yang tidak kalah pentingnya pada proses penyelesaian sengketa pertanahan di Kecamatan Manngarabombang, Kabupaten Takalar adalah kurangnya Sumber Daya Manusia (SDM) yang memiliki latar belakang hukum atau yang memiliki kapasitas negosiasi yang memadai pada Kantor Kecamatannya.

Hal itu diakui juga oleh Muhammad Arif selaku Sekretaris Kecamatan Manngarabombang, Kabupaten Takalar, bahwa dalam pelaksanaan mediasi memang hanya camat yang berberan lebih aktif dan paling-paling dibantu oleh beberapa orang saja, sementara kalo Tim Mediasi itu tidak ada secara permanen dibentuk, terus terkait dengan pegawai yang memiliki latar belakan hukum pendidikannya itu hanya dua orang saja.

Dari informasi di atas, sangat perlu dilakukan perbaikan SDM khususnya menambah pegawai dengan latar belakan hukum pendidikannya. Kecamatan memiliki peran penting dalam pelayanan terhadap masyarakat setempat, baik untuk pelayanan biasa, maupun pelayanan atas suatu konflik. Apalagi status kecamatan kini merupakan perangkat daerah kabupaten/kota yang setara dengan dinas dan lembaga teknis daerah. Tidak lagi semata hanya merupakan satuan wilayah kekuasaan pemerintahan, melainkan sebagai satuan wilayah kerja atau pelayanan.

\section{KESIMPULAN DAN SARAN}

Proses pelaksanaan mediasi dalam penyelesaian sengketa pertanahan di Kecamatan Manngarabombang, Kabupaten Takalar dilaksanakan dengan melibatkan berbagai pihak diantaranya, Camat, kedua belah pihak, Kepala Desa, Kepala Dusun, Bimmas,dan Babinsa. Proses pelaksanaan mediasi dimulai dengan mengumpulkan informasi atas sengketa tersebut dan kemudian pemanggilan para pihak. Hasil mediasi dalam penyelesaian sengketa pertanahan di Kecamatan 
Manngarabombang, Kabupaten Takalar berhasil mencapai kesepakatan perdamaian antara kedua belah pihak, akan tetapi hasil perdamaian tersebut tidak memiliki kekuatan eksekusi apabila dikemudian, hari ternyata salah satu pihak mengingkarinya. Hal itu dikarenakan hasil kesepakatan hanya dibuat dalam Berita Acara Mediasi (BAM) yang dibuat oleh camat serta tidak dibuat dalam akte perdamaian dan daftarkan di Pengadilan Negeri. Sementara faktor yang menghambat mediasi penyelesaian sengketa pertanahan di Kecamatan Manngarabombang, Kabupaten Takalar tidak terlepasdari tiga faktor, yaitu; pertama kedua belah pihak tidak terlalu memahami hukum, khususnya hukum pertanahan, kedua, adanya campur tangan pihak luar yang selalu mencampuri kedua belah pihak, dan ketiga, kurangnya Sumber Daya Manusia (SDM) pada kantor kemacamatan yang memiliki kapasitas keahlian negoasiasi dan pemahaman mendalam tentang hukum.

\section{DAFTAR PUSTAKA}

Armstrong, Michael. 1994. Manajemen Sumber Daya Manusia: A Handbook Of Human Resource Management. PT Elex Mediakomputindo. Jakarta.

Bambang Sutiyoso. 2008. Hukum Arbitrase dan Alternatif Penyelesaian Sengketa. Gama Media, Yogyakarta. Cetakan Pertama.

Bunga Desyana Pratami. 2018. Penyelesaian Sengketa Pertanahan Melalui Mediasi (Studi Kasus Kantor Pertanahan Wilayah Daerah Istimewa Yogyakarta.

Teisis Hukum. Universitas Islam Indonesia. Yogyakarta.

Bernard Raho. 2007. Teori Sosiologi Modern. Prestasi Pustaka Publisher, Jakarta.

Boedi Harsono. 2008. Hukum Agraria Indonesia, Sejarah Pembentukan Undang- Undang Pokok Agraria, Isi dan Pelaksanaannya. Djambatan, Jakarta.

Dedy Mulyana. 2019. Kekuatan Hukum Hasil Mediasi di Luar Pengadilan Menurut Hukum Positif. Wawasan Yuridika.Fakultas Hukum Universitas Pasundang, Bandung. Indonesia.

DY. Witanto. 2012. Hukum Acara Mediasi dalam Perkara Perdata di Lingkungan Peradilan Umum dan Peradilan Agama Menurut PERMA No. 1 Tahun 2008. Alfabeta, Bandung.

Edi As`adi. 2012. Hukum Perdata dalam Persfektif Mediasi (ADR) di Indonesia. Graha Ilmu, Yogyakarta.

Fred. Schwarz. 1960. You Can Trust the Communists. New Jersey: Prentice-Hall, Inc, Englewood Cliffs.

Frans Hendra Winarta. 2012. Hukum Penyelesaian Sengketa Arbitrase Nasional Indonesia dan Internasional. Sinar Grafika, Jakarta.

Gatot P Soemartono. 2006. Arbitrase dan Mediasi di Indonesia. PT. Gramedia Pustaka Utama, Jakarta.
Gunawan Widjaja dan Ahmad Yani. 2003. Hukum Arbitrase. Cet.3. PT. Raja Grafindo Persada, Jakarta.

Herlina Ratna Smbawa Ningrum. Analisis Hukum Sistem Penyelesaian Sengketa atas Tanah Berbasis Keadilan. Jurnal Pembaharuan Hukum. Volume 1. Nomor. 2. Agustus 2014.

http://www.bpn.go.id/Program Penanganan Kasus. Diakses tanggal 22 Agustus 2020; Idtesis.com. Metode Penelitian Hukum Empiris dan Normatif. Diakses pada tanggal 25 Agustus 2020. https://idtesis.com/metode-penelitian-hukumempiris-dan-normatif.

I Talib. 2013.Bentuk Putusan Penyelesaian Sengketa Berdasarkan Mediasi. Jurnal Lex et Societatis. Volume 1. Nomor 1.

I Made Winky Hita Paramartha. Kekuatan Hukum Mediasi Sebagai Salah Satu Alternatif Penyelesaian Sengketa Pertanahan.

I Wayan Wiriyawan dan I Ketut Artadi. 2010. Penyelesaian Sengketa di Luar Pengadilan. Udayana University Press, Dempasar.

Jimly Jose Sembiring. 2011.Cara Menyelesaikan Sengketa di Luar Pengadilan, Negosiasi, Mediasi, Konsiliasi, dan Arbitrase. Visimedia. Cet ke-1

Juwita Tarochi Boboy, Budi Santoso, Irawati. Penyelesaian Sengketa Pertanahan Melalui Mediasi Berdasarkan Teori Dean G. Pruitt dan Jeffrey Z. Rubin. Jurnal Notarius. Volume 13 Nomor 2. Tahun 2020.

Joni Emirzon. 2001. Alternatif Penyelesaian Sengketa di Luar Pengadilan. PT. Gramedia Pustaka Utama, Jakarta.

Kertapradja Koeswara. Peranan dan Kedudukan Camat dalam Sistem Pemerintahan Negara Kesatuan Republik Indonesia. Jurnal Forum Democratic Reform Support Program. Jakarta. 2007.

Lisa A. Lomax. 2003. Proceedings: Rangkaian Lokakarya Terbatas Hukum Kepailitan dan Wawasan Hukum Bisnis Lainnya: Tentang Penyempurnaan Undang-Undang Kepailitan. Penerbit PPH, Jakarta.

M. Fuady. 2005. Pengantar Hukum Bisnis, Menata Bisnis Modern di Era Global. Citra Aditya, Bandung

Mudjiono. Alternatif Penyelesaian Sengketa Tanah di Indonesia melalui Revitalisasi Fungsi Badan Peradilan. Jurnal Hukum, 2007, Vol. 14.

Mulyani Zulaeha. Mediasi Intrest Based Dalam Penyelesaian Sengketa Tanah. Jurnal Ilmiah Fakultas Hukum Universitas Udayana. Kertha Patrika. Volume 38 Nomor 1 Januari-April 2016.

Muhammad Rasyad. Pembuatan Akta Perdamaian Dalam Penyelesaian Sengketa Tanh Ulayat Melalu Notaris di Kabupaten Agam. Jurnal Soumatera Law Review. Volume 2. No.1. 2019.

Priyatna Abdurrasyid. 2002.Arbitrase dan Alternatif Penyelesaian Sengketa. Fikahati Aneksa/BANI, Jakarta. 
Rusmadi Murad. 2007. Penyelesaian Sengketa Hukum Atas Tanah. Alumni. Bandung. n.d.

Rusmadi Murad 2007. Menyingkap Tabir Masalah Pertanahan. Mandar Maju, Bandung.

R. Usman. Pilihan Penyelesaian Sengketa di Luar Pengadilan. PT. Citra Aditya Bakri. Bandung. 2003. Sebagaimana dikutip dari Jurnal Soumatera Law Review. Vol. 2 Nomor. 1. Tahun 2019.

Sudikno Metrokusumo.2012.Teori Hukum. Cahaya Atma Pustaka, Yogyakarta.

Takdir Rahmadi. 2010. Mediasi Penyelesaian Sengketa Melalui Pendekatan Mufakat. Raja Grapindo Persada, Jakarta.

Teguh Prasetyo dkk. 2013.Hukum dan Undang-Undang Perkebunan. Bandung. Nusa Media.

Peraturan Perundang-Undangan;

Peraturan Pemerintah No. 54 Tahun 2000 tentang Lembaga Penyedia Jasa Pelayanan Penyelesaian Sengketa Lingkungan Hidup di Luar Pengadilan.

Peraturan Presiden Republik Indonesia Nomor 20 Tahun 2015 tentang Badan Pertanahan Nasional.

Peraturan Mahkamah Agung Nomor 1 Tahun 2016 tentang Prosedur Mediasi di Pengadilan.

Peraturan Menteri Agraria dan Tata Ruang/Bapan Pertanahan Nasional Nomor 11 Tahun 2016 tentang Penyelesaian Sengketa Pertanahan;

Peraturan Kepala BPN RI Nomor 3 Tahun 2011 tentang Pengelolaan Pengkajian dan Penanganan Kasus Pertanahan.

Sirih, S. H., Ismail, I., \& Juharni, J. (2019). Strategi Pengembangan Sumber Daya Manusia Pada BKPSDM Kabupaten Majene. Jurnal Paradigma Administrasi Negara, 1(2), 5-11. 